\title{
Cervical intramedullary granuloma of Brucella: a case report and review of the literature
}

\author{
Kemal Nas $\cdot$ Nebahat Tasdemir $\cdot$ Erkan Cakmak $\cdot$ Mustafa Serdar Kemaloglu $\cdot$ \\ Yasar Bukte $\cdot$ Mehmet Faruk Geyik
}

Received: 2 March 2006/Revised: 22 September 2006/ Accepted: 18 October 2006/ Published online: 14 November 2006

(C) Springer-Verlag 2006

\begin{abstract}
The aim of this study was to present a unique case of intramedullary brucellar granuloma (IBG) and to discuss the diagnosis and management. To our knowledge, only one case of thoracic IBG has been reported previously, and our case is the first in cervical spine. A 35-year-old female patient was admitted with headache, pain and weakness in her four extremities. She had no gastrointestinal symptoms and fever. She had been diagnosed with Brucella meningitis 3 months ago and a triple therapy of doxycyclin, rifampicin and trimetoprim/sulfametoxazol (TMP/SMZ) had been started. Medical history revealed that she had ingested raw cheese and taken her medication improperly. Loss of strength was detected in her four extremities, which led us to assume the formation of a mass lesion at cervical level. Therefore, we performed a magnetic resonance
\end{abstract}

\footnotetext{
K. Nas $(\bowtie)$

Department of Physical Medicine and Rehabilitation,

University of Dicle, Diyarbakir, Turkey

e-mail: knas@dicle.edu.tr

N. Tasdemir

Department of Neurology, University of Dicle,

Diyarbakir, Turkey

E. Cakmak · M. S. Kemaloglu

Department of Neurosurgery, University of Dicle,

Diyarbakir, Turkey

Y. Bukte

Department of Radiology, University of Dicle,

Diyarbakir, Turkey

M. F. Geyik

Department of Clinical Microbiology and Infectious

Disease, University of Dicle, Diyarbakir, Turkey
}

imaging scan and found enhancement of an intramedullary mass lesion at cervical 1-2 level. Diagnosis of neurobrucellosis was confirmed by titer of $>1 / 160$ Brucella antibodies both in blood and cerebrospinal fluid. Based on these findings, brucellar granuloma of cervical spine was diagnosed and a combination therapy of doxycyclin, TMP/SMZ and rifampicin was administered for additional 6 months. At the ninth month of treatment, the patient recovered both radiologically and clinically. Our case is unique, in terms of cervical IBG formation. The excellent response to antimicrobial therapy in our patient suggests that, a trial of medical treatment for 6 months may be effective in such cases.

Keywords Intramedullary - Cervical · Granuloma . Medical treatment $\cdot$ Neurobrucellosis

\section{Introduction}

Brucellosis is an infection caused by intracellular bacteria of the genus Brucella. B. melitensis is the most virulent and most widely encountered of all the species [4]. The natural reservoir of the Brucella is domestic animals such as sheep, goats, cattle, camels, dogs and pigs. The disease is transmitted to humans by direct contact or through the consumption of raw meat, milk or milk products of the infected animals $[4,8,11]$.

Although it has been eradicated in most European and North American countries, it is still an important public health problem throughout the world, in particular, in the Mediterranean region including Turkey, the Arabian Peninsula, the Indian subcontinent, Mexico and some parts of Central and South America [4, 9, 
19]. While brucellosis affects the nervous system, it is called as neurobrucellosis. Neurobrucellosis can occur in the form of acute meningitis, meningoencephalitis, cerebellitis, myelopathy, cranial neuropathy or radiculopathy. If not treated early, neurobrucellosis can result in severe neurological morbidity and sequale, which may be irreversible [21]. The spinal form of brucellosis has no specific symptomatology or clinical findings; therefore, a high index of suspicion is necessary for the correct and early diagnosis. Its effect on the spinal cord may be due to the compression of abscess or granuloma $[9,12,18]$. Intramedullary spinal cord abscess or granuloma due to Brucella, is extremely rare. Only five other cases have been reported so far; however, neither of them had cervical spine localization $[4,6,14,17,21]$. Here, we reported a female patient receiving rifampicin, tetracycline and trimetoprim/sulfametoxazol (TMP/SMZ) because of formerly diagnosed Brucella meningitis who developed neurological deficits along with cervical spinal cord granuloma due to brucellosis $[4,16]$. Although, there are four previous reported cases of intramedullary brucellar granuloma (IBG) in thoracic spinal cord and one intramedullary abscess at conus medullaris [21], to our best of the knowledge, this is the first reported case of intramedullary granuloma of the cervical spine in the literature (Table 1).

\section{Case}

A 35-year-old female patient, living in south east Anatolia of Turkey, was admitted to our hospital, complaining of headache, pain and weakness in her four extremities, without any gastrointestinal symptoms and fever. Her history revealed that she had consumed cheese, made using raw goat's milk.

First, antibiotics had been started for presumed tuberculosis. Two weeks later, she had been re-examined and tuberculosis was excluded, then the antituberculous treatment had been stopped. Approximately, 3 months ago she was treated for Brucella meningitis with rifampicin, doxycycline, TMP/SMZ, for 45 days in another hospital. While medical treatment for brucellosis was going on, a progressive loss of strength appeared in her extremities throughout the last four weeks. She was subsequently brought to our hospital because of fever and headache and then hospitalized. Physical examination on admission revealed low grade fever without any organomegaly. Neurological examination revealed hyperactive patellar and Achilles reflexes, negative bilateral Babinsky reflex; positive nuchal rigidity, positive Kerning and Brudzynsk signs with normal proprioception and hypoestesia below the $\mathrm{C}_{2}$ dermatome. Muscle strength in both upper and lower extremities were $3 / 5$ bilaterally,

Table 1 Characteristics of neurobrucellosis patients with intramedullary spinal cord involvement in the literature [21]

\begin{tabular}{|c|c|c|c|c|c|c|c|c|}
\hline Case & Age/sex & Risk factor & Lesion & $\begin{array}{l}\text { Pus } \\
\text { culture }\end{array}$ & $\begin{array}{l}\text { Blood } \\
\text { culture }\end{array}$ & Serology & Treatment & $\begin{array}{l}\text { Systemic } \\
\text { brucellosis }\end{array}$ \\
\hline $\begin{array}{l}\text { Çokca et al. } \\
{[6]}\end{array}$ & $\begin{array}{l}\text { Seventeen- } \\
\text { year-old } \\
\text { boy }\end{array}$ & $\begin{array}{l}\text { Regular } \\
\text { consumption of } \\
\text { cow's milk }\end{array}$ & $\begin{array}{l}\text { Intramedullary } \\
\text { dermoid } \\
\text { cyst (T11- } \\
\text { L2) }\end{array}$ & $\begin{array}{l}\text { Brucella } \\
\quad \text { abortus } \\
\text { biotype } 3\end{array}$ & $\begin{array}{l}\text { Brucella } \\
\quad \text { abortus } \\
\text { biotype } 3\end{array}$ & $\begin{array}{l}\text { Not } \\
\quad \text { mentioned }\end{array}$ & $\begin{array}{r}\text { Surgical }+ \\
\text { medical }\end{array}$ & Present \\
\hline $\begin{array}{l}\text { Bingöl et al. } \\
\text { [4] }\end{array}$ & $\begin{array}{l}\text { Forty- } \\
\text { year-old } \\
\text { female }\end{array}$ & $\begin{array}{l}\text { Raising sheep and } \\
\text { consuming raw } \\
\text { milk }\end{array}$ & $\begin{array}{l}\text { Intramedullary } \\
\text { granuloma } \\
\text { at T5 }\end{array}$ & Not done & No growth & Positive & Medical & Present \\
\hline $\begin{array}{l}\text { Novati et al. } \\
\text { [17] }\end{array}$ & $\begin{array}{l}\text { Twenty- } \\
\text { four- } \\
\text { year-old } \\
\text { male }\end{array}$ & $\begin{array}{l}\text { Consumption of } \\
\text { fresh goat's } \\
\text { cheese }\end{array}$ & $\begin{array}{l}\text { Intramedullary } \\
\text { abscess at } \\
\text { T3 }\end{array}$ & Not done & $\begin{array}{l}\text { Brucella } \\
\quad \text { melitensis }\end{array}$ & Positive & Medical & Present \\
\hline $\begin{array}{l}\text { Helvaci et al. } \\
\text { [14] }\end{array}$ & $\begin{array}{l}\text { Fifteen- } \\
\text { year-old } \\
\text { girl }\end{array}$ & $\begin{array}{l}\text { Consumption of } \\
\text { cheese made } \\
\text { from raw goat's } \\
\text { milk }\end{array}$ & $\begin{array}{l}\text { Intramedullary } \\
\text { abscess at } \\
\text { T11-T12 }\end{array}$ & No growth & No growth & Positive & $\begin{array}{r}\text { Surgical + } \\
\text { medical }\end{array}$ & Present \\
\hline $\begin{array}{l}\text { Vajramani } \\
\text { et al. [18] }\end{array}$ & $\begin{array}{l}\text { Forty- } \\
\text { year-old } \\
\text { female }\end{array}$ & $\begin{array}{l}\text { Living near } \\
\text { abattoir goat's } \\
\text { milk }\end{array}$ & $\begin{array}{l}\text { Intramedullary } \\
\text { abscess at } \\
\text { conus }\end{array}$ & $\begin{array}{l}\text { Brucella } \\
\quad \text { melitensis }\end{array}$ & $\begin{array}{l}\text { Brucella } \\
\quad \text { melitensis }\end{array}$ & Positive & $\begin{array}{r}\text { Surgical + } \\
\text { medical }\end{array}$ & Present \\
\hline $\begin{array}{l}\text { Present case } \\
\quad 2003\end{array}$ & $\begin{array}{l}\text { Thirty- } \\
\text { five- } \\
\text { year-old } \\
\text { female }\end{array}$ & $\begin{array}{l}\text { Consumption of } \\
\text { cheese made } \\
\text { from raw goat's } \\
\text { milk }\end{array}$ & $\begin{array}{l}\text { Intramedullary } \\
\text { abscess at } \\
\text { C1-C2 }\end{array}$ & Not done & Not done & Positive & Medical & Present \\
\hline
\end{tabular}


indicating muscle weakness in all the four limbs. After a 3-week period of the triple anti-brucellar treatment, she was able to stand and walk with minimal assistance without any device.

Laboratory evaluation revealed normal complete blood cell count, blood chemistry and urinary analysis. The erythrocyte sedimentation rate was $26 \mathrm{~mm} / \mathrm{h}$ and C-reactive protein was $13 \mathrm{mg} / \mathrm{dl}$. Blood brucella Wright titer was $1 / 320$ and Rose Bengal test was positive. The cerebrospinal fluid (CSF) had a clear appearance with chloride $121 \mathrm{mEq} / \mathrm{dl}$, protein $200 \mathrm{mg} /$ $\mathrm{dl}$, glucose $32 \mathrm{mg} / \mathrm{dl}$ (simultaneous blood glucose $120 \mathrm{mg} / \mathrm{dl}$ ) and CSF brucella titer was 1/160. There were 150 per $\mathrm{mm}^{3}$ leukocytes (95\% lymphocytes) in CSF. Thus, the patient was diagnosed with Brucella meningitis. Cranial magnetic resonance imaging (MRI) gave normal images. Post contrast cervical MRI at July 2003 revealed an enhancement of $10 \times 20 \mathrm{~mm}$ intramedullary mass in T1-weighted images and intensity changes at the $\mathrm{C} 1-\mathrm{C} 2$ level (Fig. 1a, b).

Based on these findings, Brucella meningitis and intramedullary cervical brucellar granuloma were diagnosed and a combination of doxycyclin $200 \mathrm{mg} /$ day, TMP/SMZ 480/2,400 mg/day and rifampicin $600 \mathrm{mg} /$ day was administered. Three weeks later, the patient was able to stand and walk without assistance. After 5 months of initial medication, CSF analysis was found to be normal. The medication was continued at the same doses with no adverse effects up to 6 months from detection of tetraparesia and 9 months from the first diagnosis of Brucella meningitis. The patient was examined after 2 years and it was found that she had no complaints or abnormal physical finding and MRI in September 2005 revealed no abnormalities (Fig. 2a-c).

\section{Discussion}

Brucellosis is a systemic infectious disease. The infection spreads hematogeneously to the tissues rich in elements of the reticuloendothelial system including liver, bone marrow, lymph node and spleen. It may also localize in other tissues including joints, central nervous system (CNS), the heart and kidneys [7, 11, 18]. Brucella reaches the CNS via either hematogeneous route or by direct extension from spondilitis.

Different types of CNS involvement in brucellosis have been reported $[1,3,4,19,21]$, with the estimated incidence varying from 5 to $25 \%$ in different series, with an average of $3-5 \%[1,15,19,21]$. Nervous system complications of neurobrucellosis include meningitis, encephalitis, brain abscess epidural abscess, demyelization syndromes and meningovascular syndromes

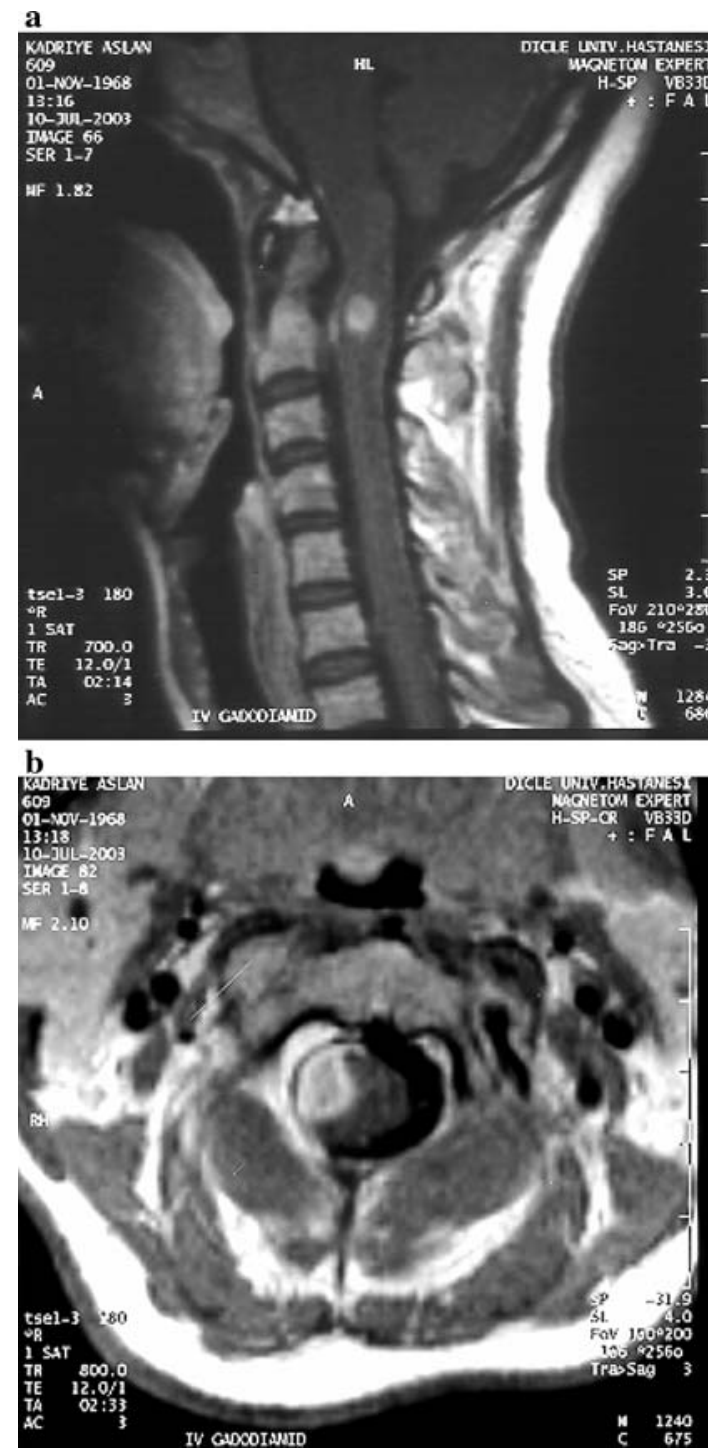

Fig. 1 a, b Contrast-enhanced T1-weighted sagittal and axial scans demonstrate intramedullary lesion with smooth margin, and homogeneous enhancement at the $\mathrm{C} 2$ level of the cervical spinal cord. At the axial scan, the lesion located on the right side of the cord and extending to the epidural space

which are rare complications of brucellosis and found in approximately $0-25 \%$ of the patients. Meningitis has been reported as the most frequent presentation, occurring in about $50 \%$ of the cases [1], but abscess and granuloma development have been rarely reported in the literature [4, 11]. A high cure rate can be achieved by treatment with triple combination, which, otherwise, would result in high mortality and morbidity. Our case received doxycyclin, TMP/SMZ, rifampicin for 6 months until CSF had been cleared. The prognosis of meningitis is usually good; however, in cases of encephalic or spinal cord involvement, mortality is not negligible and sequel is frequent [2]. 

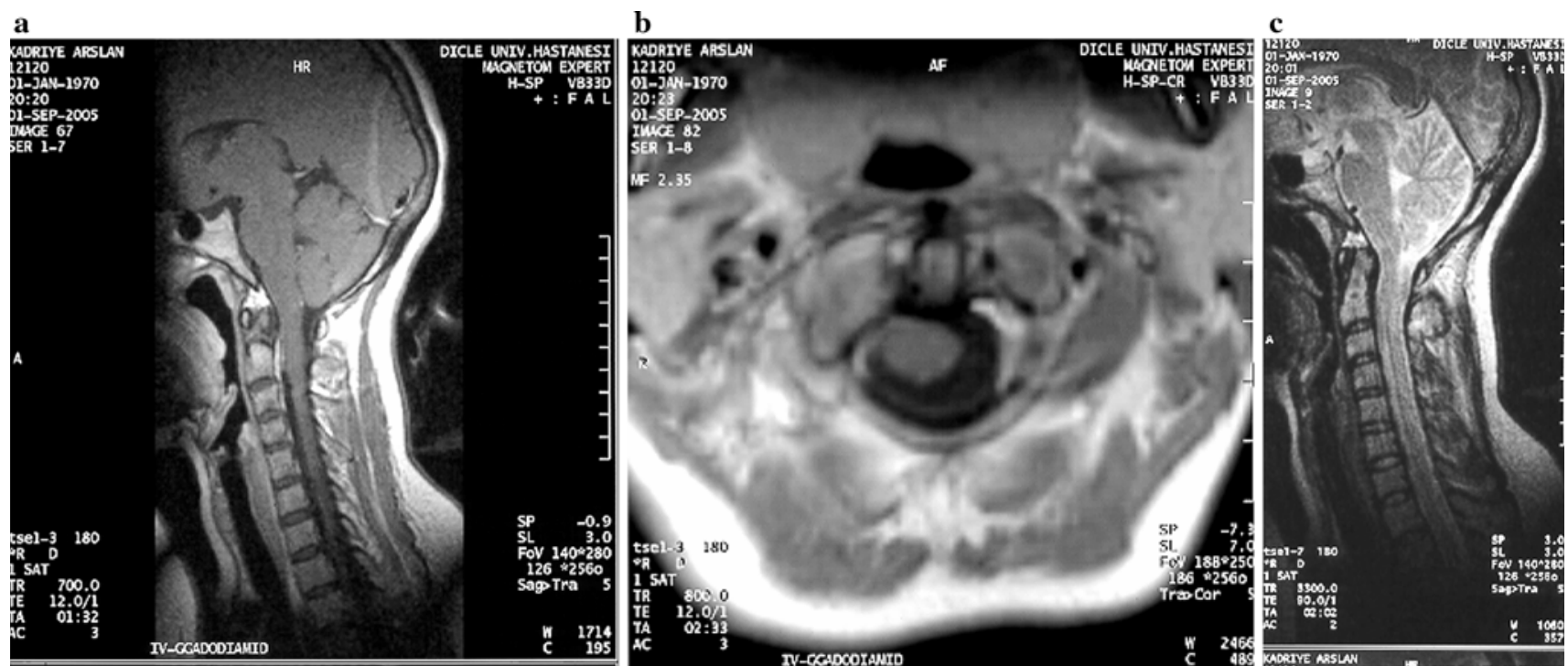

Fig. 2 Post medication images after 2 years. a, b Contrast-enhanced T1-weighted sagittal and axial scans; contrast enhancement and thickening are not present. c T2-weighted sagittal scan; the lesion and thickening are not seen

Neurobrucellosis is categorized according to the clinical manifestation, that is, CNS or peripheral nervous system involvement or a combination [13]. Neurobrucellosis can be diagnosed by raised brucella titers in the CSF, which was also detected in the present case. In addition, three types of images in the nervous system had been reported; inflammation that may cause granulomatous formation, vascular insult and white matter changes. In the case of neurobrucellosis, other possibilities of infection or inflammatory diseases including tuberculosis, fungal infections and sarcoidosis should be ruled out. In our case, negative cultures for tuberculosis and fungi and positive CSF Brucella antibody titers together with complete improvement with anti-Brucella treatment sufficiently proved the diagnosis. We believed that Brucella reached CNS via hematogenous route in our case. We could not say absolutely, but we speculated that brucellosis must have been spread to cervical spinal cord by CSF route. Although the high frequency of sensorineural hearing loss was reported in Brucella meningitis, the auditory system of our case was intact [13].

Brucellosis is not uncommon in south east of Anatolia of Turkey. Various forms of brucellosis including neurobrucellosis, have been reported from this region $[9,11,16]$. However, none of them had an intramedullary involvement of spinal cord. There are only five previous reports of intramedullary involvement by Brucella in the literature (Table 1). Systemic brucellosis was seen in all of them including the present case. Only in the present case, intramedullary spinal cord abscess was found at cervical area. In the case of Cokca et al. an intramedullary dermoid cyst, which infected by Brucella abortus has been reported and at surgery, multiple cavitary abscesses were drained [6]. Novati et al. have reported a patient with a brucellar focal abscess within the dorsal tract of the spinal cord. Antibiotics have been given for a period of 6 months and the abscess was resolved with only medical treatment [17]. In another study, an IBG has been found on MRI scan. After an extended period of antibiotics, the complete resolution of the lesion was seen on the follow-up scan [4]. Vajramani et al. reported an intramedullary abscess at conus medullaris. At 2-year follow-up, her strength loss has continued in both lower extremities [21].

Magnetic resonance imaging was the crucial step in making a differential diagnosis. MRI is the best choice in differential diagnosis of spinal brucellosis either for the vertebral, interosseos, subligamentous and paraspinal lesions or for the intraspinal granulomas [5].

In the spine, an infection associated with granulomatous reaction is most often caused by tuberculosis. Spinal cord compression has been more frequently observed in tuberculosis $(26.7 \%)$ than in brucellosis (10.5\%) [16]. Spinal granuloma or abscess because of brucellosis may cause upper or lower motor neuron type lesion [10]. Although there have been many reports of spinal brucellar abscess and granuloma, except one, they are all localized extradurally.

Treatment of spinal brucellosis is medical; bed rest, nonsteroid antienflamatuar drugs and antimicrobial therapy. Although neurological symptoms are considered an indication for surgery in brucellar granulomas, most authors now consider operation for brucellar abscess as a last choice because it responds surprisingly 
well to antibiotics [4]. However, in the presence of extensive vertebral involvement, spinal cord compression and instability, early surgical decompression and stabilization should be performed [20]. In our case, we did not perform early surgical intervention due to risky localization of the lesion ( $\mathrm{C} 1-\mathrm{C} 2$ levels), i.e., nearby to vital centers of bulbus. There are no specific guidelines for the antibiotic regimens and duration of treatment for neurobrucellosis. In neurobrucellosis, the duration for ideal therapy is uncertain and depends on the individual case, surgical or medical mode of therapy and response to treatment; it can range from 3 months to 2 years, because of the high relapse rate, even in adequately treated cases $[4,21]$. The criteria for cessation of therapy are complete clinical stabilization of symptoms, return of the CSF glucose to normal levels with a drop in the CSF cell count below 100 per $\mathrm{mm}^{3}$, and lowering of the CSF protein and antibody levels [4]. These criteria were achieved by the fifth month of therapy in our patient. Antibiotics such as doxycycline, rifampicin and TMP/SMZ have been shown effective due to their good CNS penetration and synergistic effects [21]. Surgical drainage is needed for abscess formation. In our case, granuloma formation was encountered instead of abscess formation, thus we did not need to biopsy the lesion. One of the most important factors that prevent us from performing biopsy is the location of the lesion, since it is very risky to biopsy at cervical 1-2 level. Since we did not see edema formation at MRI scan we did not give steroids as an associate treatment modality.

\section{Conclusions}

Cervical IBG can be included in preoperative differential diagnosis list of intraspinal masses, particularly in the endemic areas. MRI should be performed in patients with spinal brucellosis and suspected vertebral involvement to monitor granuloma formation and prevent cord compression. The excellent response in our patient with brucellar granuloma encourages a trial of medical treatment with an adequate dosage for a 9-month period before considering surgical intervention, even in patients with major neurological deficits or mass lesions.

\section{References}

1. Al Deeb SM, Yaqub BA, Sharif HS, Phadke JG (1989) Neurobrucellosis: clinical characteristics, diagnosis, and outcome. Neurology 39:489-501
2. Al-Sous MW, Bohlega S, Al-Kawi MZ, Alwatban J, McLean DR (2004) Neurobrucellosis: clinical and neuroimaging correlation. AJNR Am J Neuroradiol 25:395-401

3. Bashir R, Zuheir Al-Kawi M, Harder EJ, Jinkins J (1985) Nervous system brucellosis: diagnosis and treatment. Neurology 35:1576-1581

4. Bingöl A, Yücemen N, Meço O (1999) Medically treated intraspinal "Brucella" granuloma. Surg Neurol 52:570-576

5. Bouza E, Garcia dr la Torre M, Parras F, Guerrero A, Rodriguez-Creixems M, Gobernado (1987) Brucellar meningitis. Rev Infect Dis 9:810-822

6. Çokca F, Meço O, Arasil E, Unlu A (1994) An intramedullary dermoid cyst abscess due to Brucella abortus biotype 3 at T11-L2 spinal levels. Case report. Infection 5:359-360

7. Coskun E, Suzer T, Yalcin N, Tahta K (1998) Spinal extradural compression caused by granuloma of brucellosis. Scand J Infect Dis 30:311-313

8. Duyur B, Erdem HR, Ozgocmen S (2001) Paravertebral abscess formation and knee arthritis due to brucellosis in a patient with rheumatoid arthritis. Spinal Cord 9:554-556

9. Geyik MF, Gur A, Nas K, Cevik R, Sarac J, Dikici B, Ayaz C (2002) Musculoskeletal involvement of brucellosis in different age groups: a study of 195 cases. Swiss Med Wkly 23:98105

10. Goktepe AS, Alaca R, Mohur H, Coskun U (2003) Neurobrucellosis and a demonstration of its involvement in spinal roots via magnetic resonance imaging. Spinal Cord 41:574576

11. Gur A, Geyik MF, Dikici B, Nas K, Cevik R, Sarac J, Hosoglu S (2003) Complications of brucellosis in different age groups: a study of 283 cases in southeastern Anatolia of Turkey. Yonsei Med J 44:33-44

12. Harman M, Unal O, Onbasi KT, Kiymaz N, Arslan H (2001) Brucellar spondylodiscitis: MRI diagnosis. Clin Imaging 25:421-427

13. Heindel W, Lanfermann H, Mesnil R, Fischbach R (1996) Infections of the cervical spine. Aktuelle Radiol 6:308-316

14. Helvaci M, Kasırga E, Cetin N, Yaprak I (2002) Intramedullary spinal cord abscess suspected of brucella infection. Pediatr Int 44:446-448

15. Nagalothimath SJ, Joglekar MD (1974) Prevalence of brucellosis in Belgaum. Bull Indian Med Assoc Bombay Branch 3:457-461

16. Nas K, Gur A, Kemaloglu MS, Geyik MF, Cevik R, Bukte Y, Ceviz A, Sarac AJ, Aksu Y (2001) Management of spinal brucellosis and outcome of rehabilitation. Spinal Cord 39:223-227

17. Novati R, Vigano MG, De Bona A, Nocita B, Finazzi R, Lazzrin A (2002) A neurobrucellosis with spinal cord abscess of the dorsal tract: a case report. Int J Infect Dis 6:149-150

18. Ozates M, Ozkan U, Bukte Y, Ceviz A, Sari I, Simsek M (1999) Lumbar epidural brucellar abscess causing nerve root compression. Spinal Cord 37:448-449

19. Shakir RA, Al-Din AS, Araj GF, Lulu AR, Saadah MA (1987) Clinical categories of neurobrucellosis. A report of 19 cases. Brain 110:213-223

20. Tezer M, Öztürk C, Aydoğan M et al (2006) Noncontiguous dual segment thoracic brucellosis with neurological deficit. Spine J 6:321-324

21. Vajramani GV, Nagmoti MB, Patil CS (2005) Neurobrucellosis presenting as an intra-medullary spinal cord abscess. Ann Clin Microbiol Antimicrob 4:14-18 